MAREK HENDRYKOWSKI

Instytut Filmu, Mediów i Sztuk Audiowizualnych Uniwersytet im. Adama Mickiewicza w Poznaniu

\title{
Trudna przestrzeń. O filmie Roberta Stando Strach ma wielkie oczy
}

\begin{abstract}
Aвstract. Hendrykowski Marek, Trudna przestrzeń. O filmie Roberta Stando Strach ma wielkie oczy [A difficult space: Robert Stando’s Strach ma wielkie oczy] "Images" vol. XXVII, no. 36. Poznań 2020. Adam Mickiewicz University Press. Pp. 157-167. ISSN 1731-450X. DOI 10.14746/i.2020.36.10.
\end{abstract}

The article analyses and interprets Robert Stando's little-known educational film Strach ma wielkie oczy [Fear has large eyes]. The film was made in 1965 and produced by the Documentary Film Studio in Warsaw. The author explores the original character of the film, reconstructing the stylistic and compositional techniques used by filmmakers, among others, in the field of cinematography (underwater photography), editing, word function, music, sound effects etc.

KEYwORDS: child, school, behavior, liminality, swimming, teaching, instruction, fear, deep water, security

Wszystkie kiedykolwiek sfilmowane przestrzenie można podzielić na trzy kategorie: łatwe, neutralne i trudne. Teoria i praktyka ruchomych obrazów znają ten fenomen od początku istnienia kinematografii. Daje się on uchwycić i opisać w antropokulturowych kategoriach poetyki doświadczenia. Przedmiotem zainteresowania poniższego studium jest trudna przestrzeń. Trudna, a więc taka, której złożony obraz ekranowy stanowi zadanie i wyzwanie, nie poddając się $\mathrm{w}$ procesie audiowizualnej percepcji łatwo dostępnemu i oczywistemu rozpoznaniu.

W obfitej, liczącej blisko setkę zrealizowanych pozycji filmografii, stanowiącej wieloletni dorobek twórczy polskiego dokumentalisty Roberta Stando, ten niezbyt znany, skromny film edukacyjny zajmuje miejsce szczególne. Mowa o nakręconym ponad pół wieku temu, w połowie lat sześćdziesiątych, króciutkim - liczącym mniej niż dziesięć minut projekcji - dokumencie opatrzonym przez autora intrygującym tytułem Strach ma wielkie oczy.

Zrobić w tamtych, niezmiernie wymagających warunkach realizacyjnych dokument obserwacyjny, którego całość akcji dzieje się na miejskim basenie, a niemałą część materiału zdjęciowego stanowią zdjęcia podwodne (sic!), było nie lada wyzwaniem warsztatowym i produkcyjnym. Ryzyko realizatorskiego fiaska w tym przypadku realnie istniało i to znaczne. W takiej scenerii warunki do kręcenia zdjęć są, delikatnie rzecz ujmując, niezbyt sprzyjające, czy tym bardziej dobre.
Images vol. XXVII/no. 36

Poznań 2020

ISSN 1731-450X

\section{Wprowadzenie}

Pierwsza lekcja 
A cóż dopiero powiedzieć o rejestracji filmowego dźwięku w znanych każdemu, kto przebywał na basenie - niemożliwych do wyeliminowania - warunkach charakterystycznego basenowego pogłosu. Kolejne niełatwe zadanie realizacyjne stanowił w dalszej fazie pracy, wymagający nie lada kunsztu, montaż nakręconego materiału.

Autor filmu dobrze wiedział, iż wyzwaniu temu mogą sprostać tylko najlepsi, najbardziej wytrawni specjaliści. Nic dziwnego, że w ekipie współtwórców natrafiamy na nazwiska z najwyższej półki rodzimej dokumentalistyki. Do współpracy nad tym nietuzinkowym dokumentem Robert Stando, filmowiec wówczas ponadtrzydziestoletni (rocznik 1931), zaprosił grono zaprzyjaźnionych z nim, a jednocześnie związanych od lat z Wytwórnią Filmów Dokumentalnych: Jerzego Gościka, Halinę Paszkowską, Krystynę Tunicką i Mariana Duszyńskiego.

Cała czwórka legitymowała się już wówczas znacznym dorobkiem dokumentalnym. Jerzy Gościk, niezwykle wszechstronny, lubiący rozmaite wyzwania i niemożności, wszystko potrafiący autor zdjęć (znany przede wszystkim z niezliczonych materiałów kręconych na potrzeby Polskiej Kroniki Filmowej), odpowiadał w filmie Strach ma wielkie oczy za obraz wizualny, Halina Paszkowska realizowała dźwięk, Krystyna Tunicka dokonała montażu warstwy dźwiękowej, a doświadczony dokumentalista Marian Duszyński całość po mistrzowsku zmontował.

Kwartet Gościk-Paszkowska-Tunicka-Duszyński, działając pod kierunkiem Roberta Stando, wykreował prekursorski w tamtych czasach rozwoju rodzimej dokumentalistyki model „trudnej” przestrzeni ekranowej, w granicach którego stanowi ona sui generis zadanie audiowizualne przedstawione swemu adresatowi.

W młodszym wieku szkolnym
Akcja filmu, zgodnie z tytułem, koncentruje uwagę widza na pokonywaniu lęku przez grono jego bohaterów. Temat filmu, nauka pływania dla dzieci, został ściśle powiązany z pokonywaniem oporu filmowanej materii. Kamerowana przestrzeń stanowi dla realizatorów rodzaj ekstremalnego wyzwania, porównywalnego z tym, z którym zmagają się na naszych oczach mali pływacy.

W pierwszej scenie obserwujemy krótkie powitanie nauczyciela $z$ grupą adeptów, a następnie odliczanie uczestników kursu. To nie żaden pusty, pozbawiony znaczenia rytuał, lecz ważny element prowadzonego szkolenia. Wyraża on nie tylko osobiste potwierdzenie faktu indywidualnej obecności na pływalni, ale i zgłoszenie własnego uczestnictwa każdego z tych młodych ludzi w zespole, który rozpoczyna ćwiczenia i naukę pływania. Moment później od ćwiczeń służących rozgrzewce rozpoczyna się prowadzona "na sucho” przez instruktora pierwsza lekcja umiejętności pływania.

Bohaterem zbiorowym i obiektem uważnej obserwacji dokonywanej w filmie Strach ma wielkie oczy jest liczna grupa młodziutkich kursantów w obowiązkowych wtedy na polskich krytych pływalniach białych strojach i czepkach, złożona z przebywających na krytym ba- 
senie kilkudziesięciorga dzieci w przedziale wiekowym określanym jako uczniowie młodsi.

Istotny okazuje się przy tym nie tyle sam ich jednakowy wiek, ile siatka zmiennych relacji i skrzętnie zanotowanych „cierpliwą” kamerą (vide klasyczna dziś koncepcja dokumentu sformułowana przez Kazimierza Karabasza) filmową interakcji. Interakcji szczególnych jednak, a mianowicie takich, których tkanka psychospołeczna współtworzy aktywną, o czym już za chwilę, przynależność do wspólnoty szkolnej mikrozbiorowości.

Zacząłem ten podrozdział dość nietypowo: od zwrócenia uwagi czytelnika na wiek dziecięcych bohaterów, bowiem niesie on $\mathrm{z}$ sobą określone dodatkowe znaczenia. Po pierwsze, tożsamy wiek wszystkich ich jednoczy; po drugie, sprawia, iż autor i widz obserwują tę grupę w szczególnej sytuacji progowej, to znaczy podczas serii indywidualnych prób przełamywania tytułowego strachu przed wodą. Angażuje uwagę przemyślana w najdrobniejszych detalach koncepcja pływackiego szkolenia. Pierwszy kontakt z wodą, obmycie twarzy, pierwsze zanurzenie w wodzie, doznanie chłodu, umiejętność brodzenia i ostrożnego stąpania po dnie, utrzymywania się w pozycji leżącej na powierzchni itd. O kolejnych nabywanych przez dzieci sprawnościach pływackich wyższego stopnia będzie jeszcze mowa za chwilę.

Kluczem do skuteczności szkolenia osiąganej w nauce pływania jest ruch. A ściślej - zespół nabytych umiejętności i zachowań ruchowych, które umożliwiają ciału utrzymanie się na wodzie i swobodne poruszanie się w niej. Behawiorysta powie, że chodzi w tym o określone wyuczone reakcje motoryczne, które uruchamiają łańcuchy odruchów warunkowych. Neobehawiorysta nie zgodzi się z tym nadmiernie uproszczonym poglądem i skoryguje go, dowodząc, że pływa się również głową.

Same odruchy warunkowe nie wystarczą, niezbędne jest myślenie, $\mathrm{w}$ trakcie pływania $\mathrm{w}$ grę wchodzą bowiem nieschematyczne i nieautomatyczne, złożone formy jednostkowych zachowań - w tym reakcje antycypacyjne zaangażowane w sprawcze działanie i umożliwiające rozwiązywanie aktualnych zadań. Oznacza to w konsekwencji, że istotą skuteczności jest w tym przypadku umiejętne sterowanie nabytym podczas nauki wzorcem zachowania. Właśnie tego należy uczyć młodych ludzi.

W kursie uczestniczą ci, którzy pływać jeszcze nie potrafią. Prowadzona systematycznie i powszechnie $\mathrm{w}$ wieku dziecięcym nauka pływania nie ma na celu wyłonienie przyszłych mistrzów sportowych w rodzaju Marka Petrusewicza, Bożeny Cedro, Teresy Zarzeczańskiej, Otylii Jędrzejczak, Bartosza Kizierowskiego, Konrada Czerniaka czy Pawła Korzeniowskiego. Chodzi w tym wszystkim o coś całkiem innego, a mianowicie o dokonywane w sposób systemowy, metodyczny i profesjonalny powszechne nauczanie, przekazywanie i zdobywanie pewnej elementarnej, a niezbędnej w życiu ludzkim umiejętności. To z kolei sprawia, że doskonale rozumiemy i akceptujemy wysiłek pe- 
dagogiczny instruktora, śledząc jedna po drugiej kolejne próby jego podopiecznych, którzy z chwili na chwilę potrafią sobie radzić $\mathrm{z}$ wodą coraz lepiej i coraz bardziej dorośle.

Siedząc przed ekranem, uczestniczymy w aranżowanej, nadzorowanej i asekurowanej przez doświadczonego fachowca lekcji pływania. Raczej zresztą przyglądamy się i asystujemy tej lekcji niż w niej rzeczywiście uczestniczymy. Poetyka doświadczenia, którą się tu posłużono, oferuje przeżycie $\mathrm{z}$ kategorii symulowanego udziału spektatora $\mathrm{w}$ cudzych realnych działaniach.

Pole kamerowej obserwacji wyznacza indywidualne i zbiorowe przejście: od braku umiejętności i ściśle $\mathrm{z}$ nim powiązanego strachu dziecka przed czymś nieznanym, a przez to trudnym, poprzez nabywanie kolejnych sprawności, aż do opanowania szeregu podstawowych zachowań, których uwieńczeniem była wtedy wręczana dzieciom po ukończeniu kursu oznaka z dumnie brzmiącym napisem „UMIEM PŁYWAĆ” albo „JUŻ PŁYWAM”.

Powtarzam: tutaj nie szkoli się ani nie rekrutuje do szkół sportowych przyszłych mistrzyń i mistrzów olimpijskich. Mówimy o prowadzonym na masową skalę kursie początkowym, którego opanowanie ma na całe życie zapewnić młodemu człowiekowi bezpieczny wstęp do wody. Ośmielenie go przez opiekuna nie oznacza bynajmniej zachęty do brawury. Aby nauczyć się pływać, trzeba jednak zdobyć się na konieczną odwagę i przełamać w sobie strach przed wodą. Instruktor na samym początku zwraca się do swoich podopiecznych w takich oto wartych przytoczenia słowach zachęty: „Więc jeszcze raz przypominam, pływanie to jest żadna sztuka. Dwie, trzy lekcje - pływacie".

Była już mowa o kilku czynnościach wstępnych, służących oswajaniu żywiołu wody. Symultanicznie odbywa się stopniowe oswajanie kamerowanej przestrzeni. W dalszym ciągu filmu obserwujemy kolejno: stąpanie po dnie bezpiecznym, zanurzanie głowy, zanurzanie głowy połączone $z$ otwarciem oczu pod wodą, zanurzanie całego ciała, proste ćwiczenia wykonywane pod wodą, wynurzanie się z głębiny na powierzchnię. Milowy krok ku zdobywanej umiejętności pływania stanowi klasyczna strzałka. Po niej leżenie małych kursantów na plecach, ruchy nóg do kraula i do stylu grzbietowego, wreszcie równie klasyczne jak strzałka pływanie pieskiem.

Z każdą następną zdobytą umiejętnością zbliżamy się do newralgicznego zadania młodych pływaczek i pływaków, jakim dla każdego z nich jest pierwsze samodzielne przepłynięcie choćby najkrótszego dystansu bez niczyjej pomocy, jednak w warunkach odpowiedniej do ryzyka asekuracji. W kulminacyjnym punkcie rozwoju akcji na ekranie, który to punkt w krótkometrażówce Strach ma wielkie oczy przypada na piątą minutę projekcji - dokładnie na wprost perspektywy, z której śledzi wydarzenia widz - tuż nad taflą wody w basenie pojawia się bardzo wyraźnie widoczny ostrzegawczy napis: GŁĘBOKA WODA.

Od tego momentu oglądamy znakomicie sfilmowane kamerowe studium dziecięcego lęku. Przestrzeń do przepłynięcia staje się dla każ- 
dego z nich wyzwaniem. Wyzwaniem, które wywołuje instynktowny strach przed utonięciem. I coraz śmielsze jednostkowe wysiłki uczących się pływaków, by go przezwyciężyć. Wiadomo: strach ma wielkie oczy. Aby go pokonać, trzeba się z nim zmierzyć.

Poszczególni kursanci i kursantki mocno przeżywają każde przekroczenie kolejnego progu wtajemniczenia w niełatwą umiejętność pływania. Odtąd, aż do samego końca dokumentu, obserwujemy jedną po drugiej indywidualne próby radzenia sobie z własnym lękiem i z kolejnymi pływackimi wyzwaniami - próby udane i nieudane, zawsze jednak pieczołowicie kontrolowane przez doświadczonego instruktora.

Mamy teraz kolejno: pierwszy w życiu skok z brzegu basenu na głęboką wodę, jeśli trzeba - asekurowany kijem basenowym przez nauczyciela pływania, następnie skok ze słupka na nogi, rzut startowy w wodną toń na głowę, zbiorowe nurkowanie oraz wyławianie przedmiotów leżących na dnie. Nasuwa się istotne pytanie: jakim obrazem ta opowieść się zakończy? Od tego końcowego akcentu zależy przecież wymowa całego filmu. Czy w pamięci widza zarejestruje się tylko ślad beznamiętnego zapisu streszczającego syntetycznie przebieg jednej lekcji, czy może - wraz z wyborem odpowiedniego ujęcia - podjęta zostanie próba przekazania mu czegoś więcej?

Klucza do realizacji tego zadania dostarcza właśnie przestrzeń, stanowiąca w dokumencie Strach ma wielkie oczy ważki aspekt filmowego wyrazu i zarazem dominantę kompozycyjną całości.

Oto rozwiązanie montażowe wybrane przez twórców. Scenę końcową wypełnia przepływanie pojedynczo szerokości basenu $\mathrm{z}$ dopłynięciem do przeciwległego brzegu. Teraz górę bierze już nie lękliwa reakcja młodych adeptów, lecz zespół zachowań aktywnych i samodzielnych. Gdy cel pływaka zostaje osiągnięty, na ekranie pojawia się stop-klatka ze zbliżeniem twarzy rozradowanego kursanta, który przed chwilą na oczach widza bezpiecznie dotarł do wyznaczonego brzegu i z promiennym uśmiechem wychodzi w naszym kierunku z basenu.

Radość ta płynie wprost $\mathrm{z}$ wyrażającego osobisty triumf poczucia, jakie daje właśnie przeżyte pokonanie kolejnego życiowego progu. Celowo podkreślam tutaj liminalny sens dyskretnego przesłania, które niesie z sobą film Roberta Stando. Jak soczewce przegląda się w nim słynne rodzime powiedzenie sprzed wieków: „takie będą Rzeczypospolite, jakie młodzieży chowanie"[1]. Pływanie i zespół umiejętności z nim połączonych staje się tutaj przenośnią. Autor dokumentalista z najwyższą uwagą i skupieniem obserwuje poszczególne dziecięce reakcje i indywidualne mikrozachowania. Zwłaszcza zachowania aktywne i sprawcze. Aktywności te wybiera i układa w wymowną sekwencję logicznie powiązanych z sobą zdarzeń, których przeżycie i osobiste przejście kształtuje młodych ludzi.

[1] Spór o to, kto pierwszy (Andrzej Frycz Modrzewski czy Jan Sariusz Zamoyski) wypowiedział te wspaniałe słowa, pozostawiam historykom literatury i paremiologom. Sentencja „Zawsze takie Rzeczypo- spolite będą jakie ich młodzieży chowanie" widnieje w akcie fundacyjnym Akademii Zamojskiej (16oo), założonej przez kanclerza Jana Sariusza Zamoyskiego. 
Co łączy wszystkie te kolejno zaprezentowane na ekranie aktywności? Otóż łączy je proces i struktura uczenia się młodych ludzi zdobywających krok po kroku pewną niezmiernie przydatną uniwersalną umiejętność. Umieliśmy, umiemy i będziemy umieć. Umiejętność pływania raz zdobyta przez człowieka - podobnie jak umiejętność jazdy na nartach, na łyżwach czy na rowerze - zostaje już w nas zapisana na zawsze jako sprawność niegdyś osiągnięta i utrwalona. Aby jednak ją zdobyć (czasownik wybrany nieprzypadkowo), trzeba poszukać w sobie podmiotu sprawczego.

Systematycznie zorganizowana, obowiązkowa, obejmująca wszystkie dzieci w wieku wczesnoszkolnym nauka pływania, pełni w tym mądrze pomyślanym przez twórców dokumencie specyficzną funkcję. Z jednej strony staje się ona cennym składnikiem racjonalnego kształtowania i polepszania środowiska społecznego (w grę wchodzi przecież możliwie najbardziej powszechnie przyswojona w młodym wieku umiejętność pływania). Z drugiej strony odnosi się do - wpisanego w film jako umiejętnie zaprojektowaną i zmontowaną autorską całość wyższego stopnia - porządku organizującego przebieg akcji i konstrukcję całości.

Na marginesie warto może zauważyć i odnotować dwa znamienne szczegóły, które przechowuje ta archiwalna taśma, zawierająca zapis szkolnego kursu pływania, uwiecznionego przez filmowców w połowie lat sześćdziesiątych. Pierwszym z nich jest uderzająca szczupłość ciała ówczesnych dzieci (to norma! dzisiaj, w dobie rosnącej otyłości, równie szczupło wygląda sylwetka tylko niewielu uczennic i uczniów w wieku wczesnoszkolnym).

Drugie z poczynionych tutaj spostrzeżeń stanowi przemiana, jaka dokonała się w ciągu półwiecza w zakresie psychospołecznej aktywności dziewcząt. W dokumencie nakręconym przez Roberta Stando reagują one na kolejne zadania i trudności raczej defensywnie i mało dynamicznie, okazując się w sumie dość biernym i strachliwym tłem akcji (z wyjątkami), podczas gdy w obecnym pokoleniu dzieci i młodzieży wychowanym przez aktywne matki i babki dziewczyny dominują aktywnością nad chłopcami, konkurując z nimi skutecznie na wszelkich polach młodzieńczej rywalizacji.

Jeśli nazwaliśmy uprzednio Strach ma wielkie oczy filmem edukacyjnym, to dlatego, że jego autor przyjął w nim perspektywę możliwie najbardziej neutralnego, zobiektywizowanego oglądu przedstawionej rzeczywistości. Zobiektywizowanego tak, ale nie znaczy to bynajmniej, iż pozbawionego wszelkich emocji. Nawet wówczas bowiem występują one i dają o sobie znać w procesie odbioru.

Konstrukcja narracyjna przestrzeni, na którą składa się wiele różnych zorkiestrowanych z sobą montażowo czynników, przede wszystkim jednak operowanie punktem widzenia (i słyszenia) oraz aranżowanie sytuacji ekranowych wraz $\mathrm{z}$ ich rozwojem i przemianą, odgrywa w tym procesie pierwszorzędnie doniosłą rolę. 
Mowa teraz nie tylko o tym jednym utworze, lecz także o licznych innych pracach Roberta Stando, nakręconych przez niego na przestrzeni wielu lat. Filmowiec ten stopniowo wypracował sobie pewien charakterystyczny modus narracji, składający się na rozpoznawalny styl. Styl, którym konsekwentnie operuje, polega na komplementarnym łączeniu „zimnych” wyznaczników zobiektywizowanego oglądu dokumentalnego z rejestrowaniem i transmisją wiązki emocji komunikowanych przez utwór jego adresatowi. W tym sensie Stando realizuje dokumenty filmowe charakteryzujące się dużym współczynnikiem empatii.

Racjonalność przemyślanego działania sprawczego bynajmniej nie wyklucza udziału ludzkich emocji. Na równi uprawnione - i w praktyce analitycznej możliwe do udowodnienia - są więc w tym przypadku dwa sprzeczne z sobą twierdzenia. Twierdzenie pierwsze, w myśl którego obserwacyjny dokument Roberta Stando od początku do końca zachowuje wobec wszelkich ukazywanych na ekranie zdarzeń „zimny” dystans neutralnego obserwatora. I twierdzenie drugie, kontradyktoryczne, w świetle którego dokument Stando nie tylko „na zimno” obserwuje i rejestruje serię sfilmowanych epizodów lekcji pływania, lecz ponadto i wraz z tym daje również adresatowi sposobność uczestnictwa, poprzez umiejętnie zorganizowaną dramaturgię oferowanego spektaklu, dzieląc się z nim przeżyciami i emocjami grupy bohaterów. Tej ostatniej służy skala trudności realizatorskich, z którymi musiała się zmierzyć ekipa współtwórców.

O klasie zdjęć Jerzego Gościka w Strach ma wielkie oczy świadczy już początkowe ujęcie: nieruchoma tafla wody pustego basenu, na który wchodzą dzieci. A potem zbiorowy portret tej grupy sfotografowanej odwrotnie, to znaczy: w lustrzanym odbiciu powierzchni wody. O rozlicznych innych właściwościach i atutach dokumentalnej fotografii w tym filmie była już wcześniej mowa. Tutaj możemy więc zająć się arcytrudnymi - i dodajmy od razu: perfekcyjnie wykonanymi - zdjęciami podwodnymi.

Zdjęcia te to warsztatowy majstersztyk Gościka. W tamtym czasie i przy tamtym mizernym poziomie bazy technicznej, jaką dysponował w Polsce operator filmowy, był to niewątpliwy wyczyn operatorski. Porównywalny z tym, $\mathrm{z}$ jakim mamy do czynienia w nakręconym dokładnie w tym samym czasie wartym przypomnienia filmie telewizyjnym Tatarak (1965), o którym będzie jeszcze mowa za chwilę.

Integralnym, pierwszorzędnie ważnym elementem zespołu nabytych zdolności pływackich jest umiejętność bezpiecznego i kontrolowanego przebywania pod wodą. Per analogiam, jest ona tym, czym w jeździe na nartach okazuje się umiejętność bezpiecznego upadku na stoku. Zejście pod wodę nie jest nigdy zadaniem prostym. Wymaga ono od śmiałka przede wszystkim dobrego opanowania całego szeregu skoordynowanych z sobą czynności. I oczywiście pokonania kolejnej bariery lęku, kojarzy się bowiem nieodparcie z tonięciem. 
Zarówno dla twórcy zdjęć filmowych, jak i dla realizatora dźwięku zanurzenie się pod wodę także oznacza wyzwanie. Aby zademonstrować, jak radzą sobie z tym niełatwym zadaniem młodzi ludzie, operator dokumentu Strach ma wielkie oczy sam zanurzył się z kamerą w basenie. Ekranowy efekt wizualny tego zabiegu polegającego na zmierzeniu się $\mathrm{z}$,trudną przestrzenią" przeszedł oczekiwania.

Podwodne zdjęcia filmowe Jerzego Gościka - ruchome fotografie tej klasy, zmysłowej wyrazistości i wizualnej urody - stanowią nie tylko na gruncie sztuki dokumentu, ale i w całej polskiej kinematografii lat sześćdziesiątych ewenement. Właściwą im klasę można zestawić tylko z podwodnymi zdjęciami filmowymi w innym jeszcze - niemal zupełnie dzisiaj zapomnianym, a wartym przypomnienia, utworze, nakręconym w tym samym roku. Utworem tym jest fabularny film telewizyjny Andrzeja Szafiańskiego Tatarak (1965), będący ekranizacją opowiadania Jarosława Iwaszkiewicza pod tym samym tytułem. Zdjęcia podwodne do filmu wykonał, zanurzając się z kamerą głęboko w toni jeziora, starszy o trzydzieści lat kolega Gościka z Polskiej Kroniki Filmowej, Sergiusz Sprudin.

Powróćmy do kwestii zasadniczej. Co w dokumencie Strach ma wielkie oczy sfotografował kamerzysta? Lekcję pływania? I tak, i nie. Owszem, lekcja pływania $\mathrm{z}$ udziałem młodych adeptów dostarczyła mu materiału zdarzeniowego. $\mathrm{O}$ wiele ważniejsze okazało się jednak w końcu coś innego. Pokonywanie życiowego progu, który oddziela „nie umiem pływać” od „umiem pływać”. Progu, którego przekroczenie nie dokonuje się w jednej chwili, lecz wymaga od każdego młodego człowieka aktu odwagi i coraz bardziej sprawnego osobistego działania.

Potrafić pływać to umieć poruszać się i właściwie zachować w „trudnej przestrzeni”. Tym, co ostatecznie zarejestrowało się na taśmie, jest przemiana osobowości zachodząca w dziecku w rezultacie opanowania przez nie strachu i zdobycia jednej z uniwersalnych sprawności dostępnych od pradziejów ludzkości. Możliwie najbardziej sugestywnemu ukazaniu tej przemiany służy całość kompozycji analizowanego dokumentu wypracowana przez realizatorów zarówno w fazie realizacji zdjęć, jak i na stole montażowym. Oni również musieli w praktyce dowieść i zaprezentować widzowi, że potrafią radzić sobie z „trudną przestrzenią”.

Dźwięk i muzyka

Robert Stando doskonale zdawał sobie sprawę z tego, że klasyczna formuła tak zwanej ilustracji muzycznej może tylko zepsuć i doszczętnie zbanalizować zamierzony efekt twórczy. Nic dziwnego, że zdecydował się zaprosić do współpracy Tomasza Sikorskiego - młodego, liczącego sobie wówczas 26 lat pianistę i kompozytora muzyki awangardowej i eksperymentalnej. Określany niekiedy zaszczytnym mianem „pierwszego polskiego minimalisty” Tomasz Sikorski (syn Kazimierza Sikorskiego, teoretyka muzyki i kompozytora) był wówczas wschodzącą gwiazdą polskiej awangardy muzycznej, absolwentem Państwowej Wyższej Szkoły Muzycznej w Warszawie i stypendystą słynnej paryskiej pedagog Nadii Boulanger. 
Minimalistyczna kompozycja Tomasza Sikorskiego, stworzona specjalnie dla potrzeb filmu Stando, odzywa się w momencie zejścia pod powierzchnię wody. Nie imituje związanych z tym wrażeń akustycznych, lecz dąży do wykreowania ich oryginalnego muzycznego ekwiwalentu. Niejako przenosi nas wyobraźnią w sferę podwodnej rzeczywistości. Nagrania muzyki dokonało słynne Studio Eksperymentalne Polskiego Radia w Warszawie. Wtopiona w ścieżkę dźwiękową i zintegrowana $\mathrm{z}$ resztą struktury kompozycyjnej filmu sonorystyczna wizja młodego kompozytora współtworzy w sugestywny sposób dobrze znany każdemu człowiekowi zespół doznań, jakie towarzyszą zanurzeniu się pod wodę.

$\mathrm{Na}$ zakończenie rozważań na temat funkcji semantycznych dźwięku i muzyki w Strach ma wielkie oczy dodajmy, iż film ten stanowi jeden z klasycznych dzisiaj przykładów twórczego udziału muzyki i dźwięku w rodzimej twórczości filmowej lat pięćdziesiątych i sześćdziesiątych (Andrzej Markowski, Jan Krenz, Wojciech Kilar, Krzysztof Penderecki, Tadeusz Baird, Włodzimierz Kotoński, Krzysztof Komeda i in.), w której celowo zniesiona została występująca zazwyczaj w standardowych rozwiązaniach dominanta warstwy wizualnej nad audialną, a liczy się koincydencja i interferencja ich obu.

Hasło wywoławcze użyte w tytule filmu Strach ma wielkie oczy może poniekąd wprowadzać w błąd. Bo też nie jest to dokument o lęku czy strachu, lecz przeciwnie, o tym, jak go pokonać i umieć sobie z nim radzić. Stando i Gościk potrafili zdramatyzować filmowo ten złożony proces psychologiczny i psychospołeczny, ukazując go poprzez serię sytuacji i mikrozachowań młodych uczestników kursu, z których każdy dąży do przyswojenia sobie zespołu nawyków i umiejętności niezbędnych w pływaniu.

Kamerowana przestrzeń audiowizualna staje się w tym dokumencie zadaniem i wyzwaniem poznawczym w podwójnym sensie: dla uczących się adeptów nauki pływania i dla realizatorów tego dokumentu, którzy, aranżując ją i organizując, sami musieli zmierzyć się z szeregiem trudności stanowiących nie lada wyzwanie techniczno-realizacyjne.

Wartość dodana dokumentu edukacyjnego o lekcji pływania, jaki nakręcił przed laty Robert Stando, daje o sobie znać w jego mądrym, dyskretnym przesłaniu. Logika rozwoju społeczeństwa i cykl życia społecznego wymaga przekazywania praktycznych umiejętności i formowania osobowości najmłodszych. Lekcje odbywane w szkole to nie wszystko. Potrzebny jest kontakt z życiem pozaszkolnym. Taki jednak, który ma wartość prakseologiczną - to znaczy służącą człowiekowi w sprawnym działaniu. $\mathrm{W}$ tym przypadku działaniem tym (sprawnością) jest umiejętność pływania.

Strach ma wielkie oczy byłby zapewne jeszcze jednym przykładem rutynowego filmu instruktażowego wykonanego "na zlecenie”, gdyby jego realizator i współrealizatorzy nie postarali się wyjść daleko poza ramy przewidziane dla tego typu zleceniowych produkcji. Do-

Wartość dodana 
dajmy, iż w tamtych odległych czasach realizacja podobnych zamówień nie należała $\mathrm{w}$ rodzimej kinematografii do rzadkości. Wprost przeciwnie, była ona, po pierwsze, powszechnie występującą normą produkcyjną wytwórni filmowych, po drugie, codziennością naszej dokumentalistyki, po trzecie, okazją do sprawdzenia swoich umiejętności - praktycznym ćwiczeniem służącym rozwijaniu własnego kunsztu realizatorskiego i filmowego warsztatu.

Uwaga powyższa dotyczy nie tylko warszawskiej Wytwórni Filmów Dokumentalnych, lecz również - a kto wie, czy nie w jeszcze większym stopniu - łódzkiej Wytwórni Filmów Oświatowych i Wytwórni „Czołówka”. W środowiskach tych przyjmowanie dokumentalnych zleceń nie stanowiło żadnej ujmy. Mogły one dotyczyć i dotyczyły najróżniejszych zamawianych tematów. Filmy zleceniowe kręcili w tamtym okresie nasi najlepsi i najzdolniejsi filmowcy dokumentaliści. Wymieńmy tylko przykładowo Marcela Łozińskiego, Krzysztofa Kieślowskiego i Wojciecha Wiszniewskiego.

W omawianym przypadku na plan pierwszy wysuwa się jednak co innego. Strach ma wielkie oczy, widać to również dzisiaj z całą wyrazistością, był filmem nader potrzebnym i cennym społecznie. Obserwując pierwszą lekcję pływania i perypetie uczących się, autor i widz stają się obserwatorami procesu przekazywania i zdobywania umiejętności, która wprawdzie nie chroni całkowicie przed utonięciem, ale zapobiega nieszczęściu i minimalizuje jego ryzyko przy założeniu racjonalności poczynań jednostki w kontakcie z głęboką wodą. Z ryzyka tego zdają sobie sprawę miliony ludzi kąpiących się bezpiecznie w morzu, w rzekach, jeziorach, stawach, basenach i wszelkiego rodzaju zbiornikach wodnych. Jednak, jak się okazuje, nie wszyscy. Nie wolno zapominać, iż każdego roku tonie w naszym kraju - z różnych powodów i w bardzo różnych okolicznościach - kilkaset osób, a sezon na topielców nigdy się nie kończy (od dawna na porządku dziennym są przecież zimowe i wiosenne tragedie na kruchym lodzie), wykazujące w corocznych statystykach zadziwiającą powtarzalność występowania.

Nie możemy jako społeczeństwo ochronić absolutnie wszystkich kąpiących się przed utonięciem. Takiej możliwości nie ma. Ale możemy - i czyniono to z powodzeniem dekady temu - spowodować, iż bardzo młodzi ludzie w wieku wczesnoszkolnym nabędą w efekcie nauki pływania praktyczną zdolność radzenia sobie $z$ wodą. Nie jest to mało, a wprost przeciwnie, bardzo wiele. $w$ wodzie, Warszawa 1986

Karabasz K., Cierpliwe oko, Warszawa 1977

Karpiński R., Karpińska M.J., Pływanie: sport, zdrowie, rekreacja, Warszawa 2009

Kotarbiński T., Abecadło praktyczności, Warszawa 1972

Kotarbiński T., Sprawność i błąd, Warszawa 1956 
Kotarbiński T., Traktat o dobrej robocie, Warszawa 1955

Linhart J., Proces i struktura uczenia się, przeł. M. Idzikowska-Szymańska, Warszawa 1972

Murch W., W mgnieniu oka. Sztuka montażu filmowego, przeł. K. Karpińska, Warszawa 2006

Wiesner W., Nauczanie - uczenie się plywania, Wrocław 1996

Scenariusz: Jan Krych, Robert Stando

F I L M O G R A F I A

Realizacja: Robert Stando

Zdjęcia: Jerzy Gościk

Dźwięk: Halina Paszkowska

Montaż dźwięku: Krystyna Tunicka

Montaż: Marian Duszyński

Muzyka: Tomasz Sikorski, realizacja Studio Eksperymentalne Polskiego Radia

Produkcja: Wytwórnia Filmów Dokumentalnych w Warszawie, 1965

Czarno-biały, czas projekcji 9 minut 35 sekund

Nagrody i wyróżnienia: Wyróżnienie Honorowe dla filmu na Międzynarodowym Festiwalu Filmów Dokumentalnych i Animowanych w Lipsku, 1965 